\title{
EUHTE3E
}

Pregledni članak

Review paper

2020, бр. 17, стр. 113-134.

UDK

doi:10.5937/sinteze9-24202

343.97

$316.356 .2-056.49-053.6$

\section{FAMILY CIRCUMSTANCES AND RELATIONSHIPS AS A FACTOR OF CHILDREN CRIME BEHAVIOR}

\author{
Mirjana M. Marković ${ }^{1}$ Miloš Lakićević ${ }^{2}$
}

Summary: Statistics show that crime rates are rising globally. Not a single period of the development of human society was spared from the pathological phenomena and deviant behavior, nor even the modern era, where an explosion of various forms of deviant behavior can actually be noticed. What are the conditions and causes that have led to such global trends? In this paper, family circumstances and relationships will be analyzed as a crime factor. We will see what the universal and unchanged characteristics of the family are, how it affects the socialization, cultivation and individualization of children. In one systematic way, we will try to respond to the universal issues of family influence on its members. What are the interactive relationships between family members? How the functional and dysfunctional families affect their members? If and how can a family create a favorable climate for deviant behavior and how to avoid the multiplication of pathological phenomena in dysfunctional families? How youth and juvenile delinquency can be connected? All these are questions that we will try to give an answer to, although this answer is unlikely to be one-dimensional, since the family is a complex social group, with a complex mechanism of action.

Key words: family, crime, socialization, children, deviant behavior, youth, juvenile delinquency.

\section{INTRODUCTION}

The human society has undergone a long developmental path through millennia, moving from one form to another, changing and developing, so that it would eventually take on the form it has today. Alongside the changes within the society, what also changed were the

\footnotetext{
${ }^{1}$ mirjanamar76@gmail.com, A vocational school for educating of teachers, in Pirot

2 milos@kib.edu.rs, Law faculty of economy and justice, in Novi Sad,
} 
structure and function of the family, which represents a historical social phenomenon that arises at a certain level of social development and develops and improves through history."It is one of the oldest primary social groups, within which a large number of social processes are realized: biological, economic, and educational-cultural." (Milić, 1981, p. 10)

The family as a parent and child community plays a major role in the formation of value and normative systems. It is the first social environment with which the child is in contact, and the social habits that a child adopts from his/her parents and the way his/her attitude will later be towards the world that surrounds him/her depends on the family. The conditions of family life, especially in the early years of childhood, are essential for the formation of child's awareness and personality. The family is not only the institution through which socialization is realized, in that sense the family acts to adopt social norms, but the family is also the factor on which depends on what kind of person the child will develop.

The way in which parents, by rewarding and punishing, are trying to achieve a child's adoption of social norms, determine not only the norms of behavior of the child, but also determine his/her personality. For the development of the future personality and the child's awareness, the most important thing is the feeling of security, the feeling of the child being loved by and taken care of by the family. Certain specific acts in relation to the child are not so important, as much the general relationship and general atmosphere in the family are, and primarily the child's sense of safety. Parents who show a warm-hearted relationship will be more effective in the process of upbrining, primarily because their children will imitate them more and will readily accept each lesson from them. The child will feel more attached to the parent who is more warm to him/her.

The process of identification with parents will be stronger, and in this way the child will better accept models of behavior of their parents. As three forms of learning by model, the following are mentioned: learning by identification, learning by imitation and learning by role learning. In the first years of life, the family has a crucial influence on the child. The child identifies with the parents, especially with the parent with whom he/she is more related. The child imitates parents and ultimately learn the roles that exist in the family.

If parents pass on their unconditional love to their child and demonstrate by their behavior that they respect all social norms and that they are appropriate members of society, the child will grow to become a socialized person in the highest percentage, ready to take on all his/her 
social roles. However, if parents show preference for crime and deviant behavior, ignore their child and do not respect the integrity of the child's personality, but directly communicate their attitudes, the child will not have much choice but to take over the behavior of his/her parents. The cycle of transferring deviant behavior from one generation to another then turns into a circle that only a responsible society can break through its mechanisms of social protection.

\section{FAMILY AS A PRIMARY SOCIAL COMMUNITY}

For the family, we can say that it represents a primary community, because it is the first, most important and most populous human group. It is, in fact, a prototype of every other social community, because it establishes permanent, emotionally intimate, solidarity and versatile connections between members. In the most general sense, the family could be defined as a historically changing social form within which the process of reproduction of individuals - members of the society takes place. On the one hand, the process of natural reproduction through processes of birth, growing up and dying, on the other hand, the process of socio-cultural reproduction, through the process of socialization, culturalization and individualization of the individual and care for the preservation of personal integrity and its members. The organization of family life, in which context this complex set of processes and relationships takes place, is a product of historical movement in which numerous economic, social and cultural factors participate (Mitrović, 1997, p. 266).

The family is undoubtedly a social group, or as Malinovski says more social and cultural than a biological unit. It is determined by certain social rules and regulations, has social goals and functions. It is also a biosocial unit, which arises not only according to social laws, rules and convention, but also according to the biological laws of reproduction and on the basis of the blood relationship between the members that make up it. The biological basis itself is not sufficient to form a family as a unit of human society. It is necessary to develop human needs (psycho-social and socio-cultural) instead of the instinct, because from the gregarious instinct and instinct of mating, neither the primitive family can be brought out, let alone the universal diffusion of the family through the entire former human history can be explained. Namely, it is only from the social need to transfer to the youth the basic principles on which a particular society is based and the social laws that result from it, and not only to reproduce the 
offspring and on the basis of the developed need to protect the progeny and enable it for human existence, that a qualitative transition from the animal to the human community arises. Therefore, the human family was never just a private matter of its members, but it always existed as a socially prescribed and sanctioned human creation, which was encouraged and considered socially desirable in all societies (therefore in some societies celibacy is treated as a social offense punishable) (Milić, 1981, p. 170).

Although in a modern society the family becomes more and more the thing of the individuals who create it, even the modern society does not cease to be interested in the family, and does not give up the sanctions by which it secures the legal basis and legitimacy of marriage and family.

The family is the primary bio-psycho-social community of parents and their own or adopted children. The family can be viewed as a specific form of organization that is created on the basis of the blood-bearing connection of members, which results from the performance of the natural reproduction function, but also which enables this function. Relation is a socio-cultural and historical category, and is based on a ban on kindreddesecration(incest-taboo).According to the method of calculating kinship, there are two types of family relationships and two great periods in the development of the family: the first is the older one - the matriarchate in which the mother was the central personality of the family, and the kinship was calculated by the mother; the second - patriarchate (in Latin: pater - father) in which the father is the main authority and kinship is counted on one's father's line. Relation is not only a biological but also a cultural and historical category, therefore, a social relationship. The biological basis of the family consists of sexual relations of the spouses and giving birth and raising offspring.

"The family is in a content, structured and formal aspect a historically variable social group, whose universal features are:

- To rest on heterosexual relationships, through which men and women satisfy natural sexual and other (spiritual, moral, aesthetic) needs and provide the reproduction of society by the birthing of offspring (the biological basis of the family);

- To base the system of akin relations which are the basis for sexual taboos and the assignment of roles within the family (bio-social basis of the family);

- To provide and develop social and individual (moral and physical) personality traits (social foundations of the family); 
- To ensure the performance of certain economic (productionconsumption or just consumption) activities within the family (economic basis of the family). " (Mladenović, 1973, p. 52)

The first identifier of the family definition indicates that it resides on biological grounds (sexual relations and biological reproduction).The biological characteristic of the family is one of its most important features. It consists of two types of relationships: sexual and reproductive. Both have an equal meaning for the family. It is undoubtedly that since the time the family originated, the birthing is mainly related to the family as a social group, as one of its main goals and tasks. What kind of functions the family will perform depends on many factors. They change as the family itself changes. On this plan, an interesting evolution can be followed: in the period of primitive family organizations, the functions of the family were not severely separated from the social, because the poorly equipped and unprotected man could not live only in the family and could not only business in it. Later, the family becomes a small society and to some extent it frees from the dependence of the society (the patriarchal family).Finally, there is a renewed significant interweaving of the family and social functions: the society takes over a considerable part of the work done by the family itself.

Regardless of the historical variability of the family, two components can be distinguished, whose content and interpersonal relationships give the family a specific historical feature. These are:

- Akin organization based on the natural reproduction process within the family, which enables the differentiation of the position and role of family members and determines its internal relations,

- Home economics, an organization that serves to meet the various needs of members, based on economic activities that the family performs directly or indirectly through the activities of its members (Milić, 1981, p. 10).

The family, as an element of the social structure, has numerous functions. Family functions are complex: biological and socio-cultural reproduction implies a complete process of raising a child to a mature person and developing a sense and a need for social communication.

Are the functions of today's family identical to family functions in the past? Did the loss of various functions in combination with a reduction in the number of family members affect the quality of family relationships? According to Aries, this contraction signified the emergence of a modern family: nuclear, intense, turned inward and concentrated on children at the expense of sociability. Aries concludes that the loss of other functions has strengthened the family (Ariès, 1973). 
Parsons points out that this type of family is most suitable to prepare individuals for their roles in a modern stratified society (Parsons \& Bales, 1955).

\section{THE IMPORTANCE THE FAMILY FOR CULTIVATION AND SOCIALIZATION OF CHILDREN}

Each society takes measures to form the proper forms of behavior of its members for the functioning of the society. Among others, certain knowledge and skills for mutual communication, attitudes and opinions for common orientation, values for achieving common goals, a certain form of active behavior for regulating affective communication among people, a certain manner of moral behavior for controlling unpleasant and socially harmful stands and actions. All of this is achieved by a lengthy process called socialization, which begins right after the birth of an individual. In order for a society to function smoothly, socialization is considered necessary.

All factors that influence the process of personalization (socialization) of persons can be conditionally divided into primary and secondary (intermedial). The primary factors include: family, kinship structures, neighbourhood, institutions specializing in socialization (preschool institutions for children, school and other educational institutions) and non-institutionalized factors of socialization (peer groups, press, radio, $\mathrm{tv}$, film, etc.).Secondary factors of socialization are such social structures that are more or less distant from the daily life of individuals and families, and who only exert an indirect influence on them, mainly through the family as a whole, determining the place, role and function of the family within a global society. These structures have a greater impact on the process of socialization of the family itself and determine its place in the structure of the entire society. The process of upbringing and socialization appears as a double process of parents' influence on children, but also children's on parents, on their education, on their self-upbringing. This process of knowingly improving the family based on contact with children is not limited to changes in education only, since such an effort by parents means improving the inner atmosphere corresponding to the tasks of education.

The first ethical attitudes, the first moral judgments and moral concepts, and the forms of behavior that are based on them are obtained in the family. The family is a mediator between the social system and the corresponding culture, and a socially yet unformed individual, whether it 
successfully carries out the process of social reproduction or it fails in it. But when asked if the family is a successful mediator, it can not be answered solely from the standpoint of the social system and its demands, i.e. to what extent it helps an individual to adapt to the given system, but also the disposition and the needs of the individual (whether the family encourages or suppresses them) must be taken into account. "The main factors on which the character of mediation in the family depends, are the personal characteristics of the parents, starting from the type of their personality, to the socially and culturally acquired characteristics, such as education, the level of knowledge and knowledge of society and culture, the value framework of orientation that they have adopted, and their the ability to get to know their own child" (Golubović, 1997, p. 158).

The child will become a person in the complex context of social life and culture which he/she first sees in his/her family, looking at the outside and still unknown world through the eyes of his/her parents or older siblings. The way this world, which he/she is still not a part of, will look to him/her depends on what his/her parents and other family members pass on from this world, how they see it and experience it, and what kind of an image about it they present, how much they participate in society and if they accept or reject that society. The way a child will understand himself/herself, where he/she will find himself/herself and how he/she will relate to his/her environment, depends on these first concepts of the "narrow" world (family) and "wide" world (society). The child receives the first basis for the development of his/her personality in the family. The type of family will significantly affect the incentives an individual receives for the development of his/her personality, since the family can suppress and restrict or free the development of the individual potentials of its members. It depends on whether the family acts in the function of socialization or encourages the processes of individualization as a complementary dimension of the constitution of a person. A child inherits from the parents certain characteristics, upon which a further development will depend to a certain extent. The inherited dispositions determine what an individual can become (this refers to intelligence, temperament, innate abilities, talent, etc.), but these can be suppressed if there are no suitable socio-cultural and family conditions for their development, i.e. they can be suppressed by inadequate upbringing. The influence of external relations and forces on the processes of upbringing and the formation of children in the family and on parental practices results in an increasing "professionalization" of the parental role, which could also be characterized as one kind of parental over organization. Under the 
influence of these external factors, parents increasingly quit or avoid developing children's sense and the need for self-regulation, self-control, autonomy and creativity, and increasingly insist on a conformist approach to non-violent adaptation to governing expectations. In an effort to realize themselves as parents, especially mothers, they resort to one dangerous instrument, possessiveness. Instead of giving children as much independence as possible, mothers are rigidly tied to children by treating them as objects in their subconscious desire for self-fulfillment and success. In such cases, excessive emotional attachment of children to the mother represents a real psychological terror against children, which is later manifesting itself through a series of disorders in the functioning of adults, and as a consequence, it may have the appearance of a different kind of pathological behavior.

In order for an individual to become a person, it is not enough for him/her to learn social rules and norms and to adapt to social demands, i.e. the socialization and discipline of the biological instincts of the newborn are not enough for those necessary lines of character that are characteristic of a mature person to be encouraged and developed. Along with the transfer of social demands and values to a child, it is necessary to stimulate both its internal dispositions and to develop the individuality and independence of the child, in order for a character to be shaped according to the nature of the given individual."Socialization of a person signifies the process of constant continuous creation of man and of humanity in every new individual and every new generation. This is primarily a process of transposing cultural values into the inner world of the individual and the development of his/her productive creative power on cultural material. But socialization has not only this dynamic revolutionary but also the conservative side - the creation based on a determined historical pre-determined pattern to be overcome" (Mladenović, 1973, p. 128).

Emile Durkheim wrote that "the goal of upbringing, the development of each individual is the perfecting of everything for what he/she is capable of", determining that the task of educating is "harmonious development of all human abilities", to "the highest point we can achieve." (Durkheim, 1956, p. 62) For Durkheim, education is related to the given society, for institutionalized social relations. As a process, it is the interaction of generations, the influence of the older on the young.

When we observe the society and its relation to the individuals that enter the process of socialization, for socialization itself we can say that it is the formation, the form of interaction and the adoption of the system of 
relations that exist in a given society, and which are embedded in the consciousness of the person. Socialization is actually a process of social learning through which an individual acquires socially relevant forms of behavior and is formed as a person with his/her specific characteristics(Rot, 1994, p. 69)." Socialization represents the totality of the process of forming a person as a member of society, family, professional, political or other group, with a system of reactions shaped by culture, cultural "consumer" and cultural creator, man of certain habits and behaviors, followers and creators of social tasks and goals. At its lowest stage, the process of socialization of the person is the process of transformation of his/her biological nature, first by the development of his/her adaptive abilities, and then by his/her rebellion, conflicts, but also by the acceptance of culture, above all social norms that will receive a specific form and a special seal in the life of the new generation. The culture that an individual adopts is "integrative in its socio-historical function (Murdock, 1940, pp. 361-370)".

The mediating role in connecting society / culture and the individual is played by the process of socialization. In this way, individuals as biological organisms become socially (human) beings, and society, thanks to socialization, establishes contact of its duration, as it constantly renews its members. By socialization, social demands and cultural values are passed on to individuals in order to fit into the given social system. But this is not a one-way process of adaptation, since individuals need to first understand the messages sent to them from the culture, and they can interpret them in different ways, and therefore respond differently to them (an example could be the child's reaction to the behavior of the mother). Some children will interpret the mildness and leniency of the mother as indecision and conclude that the requirements set out need not be fulfilled and they will avoid discipline; another child in the same family, who will try to satisfy his/her mother precisely because of her mildness, will strive to behave in accordance with the set norms, not only to avoid punishment, but also to get the mother's love.

The process of socialization is always a process through which members of society adopt the forms of behavior that an individual learns. All models which need to be adopted are forms of behaviors that exist in a particular culture and are required or considered to be desirable in it. The rules on how to eat, rest, treat other people, interpret the world around them, are the regulations and the understanding of a particular culture. Culture and the society to which the individual belongs, represent the main source of socialization. Socialization is realized through the actions 


\section{2}

of other persons and institutions that represent the factors through which the society seeks to adopt certain forms of behavior. These factors are the tools of society and their agents (Rot, 1994).

Essential for the socialization of the person is the development of man's knowledge, abilities and skills, to those boundaries that have been set by nature and social circumstances. This development is achieved by selective interiorization of cultural heritage. A special value for explaining the process of socialization have researches conducted by A. Bandura with his associates in the 1960s, as well as his discussions on the nature of social learning. This learning is learning based on observing others' behaviors. We have such a learning when new forms of behavior are acquired, or when certain forms behavior that the individual has already acquired are modified, and only on the basis of observing the behavior of others, without attempting to engage and learn such behavior, simply by the direct imitation of the behavior of a model. Such observational conditioning, in the opinion of Bandura, is usually based on the principle of instrumental conditioning. It is imagined and estimated that by imitating some form of others' behavior, we can attain a reward, or some satisfaction for ourselves, that the implied behavior of the behavior has an instrumental value for us. Children in the first years of life imitate the behavior of their parents. They observe their reactions to a variety of situations, and the children respond to the same situations in the same way. The goal of socializing a person is to create a useful socially responsible and morally autonomous person guided by his/her own consciousness. This is the process of individualization, the process of personalization, the forming of a human personality.

The social person connects with the rest of the world, satisfying his/her own needs, but satisfying the social needs as well, taking care of himself/herself and of other people. This process of "social expansion", the connection of a young man with a narrow and wide environment, even with the whole humanity, not only on logical but also on an affective basis, has enormous significance, which is especially reflected in the creation of ecological and cultural protection of the environment, not only at the local but also at the global level.

It can be said that the process of socialization takes place in parallel with the process of individualization, since social incentives simultaneously influence both the stronger and weaker development of individual dispositions, and in accordance with them, individuals respond to the demands of society and culture. Accordingly, the process of socialization represents the harmonization of individual dispositions and 
needs with the social needs and requirements set by the social institutions in which individuals are included (the only universal socialization institution is the family).

Intensive family interaction, caused by a greater harmony and the continuity of the family structure, affects the modern family so that it becomes not only more intense in its feelings, but more selfish. People who live together for a long time are prone to turn to each other and live in separate closely related groups. Certain habits, attitudes, and reactions emerge from a long lasting cohabitation. Certain forms of interconnection within the family become rituals. This individualism can lead to the creation of a special family language. The increase in intimacy and individualization seems to lead to the isolation of the modern family. The contrast between private and public life has become more distinct. The greater consistency of the family group can be compared with the increasing mobility of the society as a whole.

In a social interaction, individuals first form social consciousness and develop the ability to understand the expectations of others in group interactions: they first evaluate themselves by looking at themselves through the eyes of others. In the process of maturation, awareness of one's own "self" is being formed, i.e. "self-awareness". Since an individual becomes human only in social relations - in which he/she finds out where his/her place in the social group is, what is expected of him/her, what he/she can expect from others, what he/she should do in order to make his/her behavior be approved, in order to receive recognition from the people he/she appreciates-forming of social awareness is a precondition for establishing self-awareness .Self-awareness as an awareness of one's own individuality, as a realistic and critical assessment of one's own "self" and the world in which the individual lives, occurs when a person is able to distance himself/herself from others (this starts with the child's independence in relation to his parents; then it continues in relation to other social and political authorities, but certain individuals will not achieve that phase and will remain bound by the obedience to authority) (Golubović, 1997, pp. 66-67).

An individual can not live outside the framework of socially defined behavior. And social behavior can be defined as a model of a desired and accepted type of interaction in a particular social group, which by means of recognized values, norms, rules and regulations regulates relations between members in a given group, between different social groups and between the society as a whole and individuals. However, in addition to the factors that emerge from the structure and nature of the 
social group, social behavior is conditioned by the initiatives of individuals, and the motivation of the participants must be examined in the conduct of the behavior.

Numerous scientific data indicate that social behavior which we encounter in members of certain societies and cultures is in a great deal a behavior that is acquired based on the looking up to other people's behavior. This is shown by, among others, numerous anthropological data.Using the model in everyday life, as the way to acquire certain forms of behavior, is so frequent that we do not even notice it. Many times these models are only symbolic, iconic models - images, showing how something should be done or verbal instructions on how to use a device.

Children most often copy their parents. It is therefore necessary that parents know what kind of personality of their children they should form and what their role is in it. In the child's attitude towards parents or adults who raise him/her, what prevails is the child's belief that everything they say is true, even when he/she does not actually listen to them."Aninfant is born in a certain social environment, and is subjected to a certain family discipline and order since the first breastfeeding and nursing, he/she grows in symbiosis with his mother, in one word, his/her behavior is conditioned by social factors from the very beginning, and therefore we could put forward the thesis that the human being will be socialized from the first day of his life equally as it would be in adulthood, and that development, on the contrary, leads to a re-individualization in which the individual partially withdraws from collective imperatives (Mladenović, 1973, p. 62)."

The personal example of parents is most appropriate because the authority of the family in the eyes of children is great. It is desirable for parents to be active citizens as much as they can, to be well informed and progressively oriented, to agree in attitudes, to show interest in work and development of children, to show patience and to persist in appropriate requirements. The very fact that a man is born, grows up, lives, grows old, and dies within in the family, speaks about the influence of the family on a person throughout his/her life. At least two to three generations meet within it, so the generation conflict is an important factor in the formation of a person and the provision of progressive understandings.

Since the family is the main mediator in child's interaction with the environment, the way parents approach the upbringing of the child plays a significant role in bringing the child into the adult world. A child lacking the guidance of parents and trust in them as trusted guides through an unknown world, may later form a more critical attitude towards the world 
and more independent understandings, more expressed self-consciousness, without paying tribute to this beneficial parental support in childhood: but for that reason, the child may remain lost in that world that is still strange to him/her, making uncertain steps to his/her independence due to the lack of elementary emotional balance which he/she failed to realize in intimate contact with the parents in early childhood. „If the family has a healthy foundation for personality development, sources of socialization and other socialization agents can hardly disrupt the proper development of an adolescent, except when it comes to the inherent tendency toward the formation of psychopathic personality traits" (Slavković \& Slavković, 2019, p. 51).

Socialization is a process that is carried out by upbringing, with the aim of upgrading the biosocial structure of the individual with such psychosocial and cultural elements that will enable him/her to live in a social environment according to the rules and norms prescribed by that environment. By socializing, an individual becomes a member of his/her own society, and since an individual can only exist as a human being only as a member of the social community, socialization is one of the basic processes through which a person is formed. So an individual is not born as a person, but he/she becomes one only by living in a social environment.

\section{FAMILY PATOLOGY AS A CAUSE OF CRIMINAL ACTION OF CHILDREN}

As seen in previous chapters, the family is crucial for the formation and development of the child's personality, for his/her socialization, individualization and cultivation. A healthy family atmosphere always has, a priori, more conditions to form a healthy offspring. Mother's relationship with her children is especially important, because of the time she spends with them during their upbringing. "The bad emotional climate of a family created by an overly protective mother leads to various illnesses and pathogenic reactions in a child" (Milić, 2001, p. 266).

Different anomalies in the family may result in many deviant behaviors, which are primarily reflected in children. A dysfunctional family characterized by alcoholism, drug addiction, abuse, sexual abuse and domestic violence can significantly contribute and influence a minor child to turn to delinquent behavior. "When it comes to integrativelydisintegrating processes within the family, it should be noted that today their importance in the production and maintenance of juvenile 
delinquency and criminalization of family members is becoming more and more evident. Earlier theories and research, as in the case of the Chicago school, emphasized the stucturical variables in explaining juvenile deviance, delinquency and submissiveness to criminal behavior such as the absence of a father due to divorce, leaving the family, widowhood, migration, etc. All contemporary research focuses first on a "poor family" rather than a "broken home" as factors responsible for the delinquency of young people, on family processes and not on the family structure, and in short on the quality of social interaction that is established between members of the family" (Milić, 2001, p. 266).

In dysfunctional families, communication and emotional relationships are disturbed, confusion or the replacement of roles in family relationships prevails, and the basic value systems of its members are mutually incompatible. In some families, interpersonal conflicts, which are normal in families, are not resolved. Conflicts get chronic, and the family continues to function in the pathological balance. They still formally function as a group, despite evident psychosocial pathology. In some dysfunctional families, interpersonal conflicts can be resolved in a drastic way, by manifesting physical aggression, both between parents and parents toward children. Finally, most often as a consequence of bad marital and family relations and conflicts, a parent divorce can occur, with which the family mostly ceases to exist as a community that provides complete protection, exchange of feelings and social experiences necessary for the development of the child. The consequences for the child's development are stronger and more pathogenic if the child is younger and if the divorce takes place in sensitive stages of development. Children whose previous mental development was endangered by poor family relationships, most often experience new wounds with divorce (Kecman, 2007, p. 30). "The product of the harshest form of unadjusted behavior is delinquency, but it occurs in situations where social incapacity is not compensated by good and consistent family relationships (Kostić, 2011, p. 484)."

Regarding the realization of family functions that are defined by the biological, economic and psychosocial level, strict criteria can be defined for assessing its functionality, as well as dysfunctionality. A functional family is one that shows a satisfactory degree of fulfilment of its basic tasks. Dysfunctional families show disorders in all or many areas of functioning."Family normality is equated with the absence of psychosocial family pathology. Nevertheless, it is evident that families continue to exist and formally function despite psychosocial pathology, so 
the question of its impact on the child, that is, the juvenile who lives, grows and develops under the auspices of such a family, is raised" (Kecman, 2007, p. 30).

Numerous studies have shown that the absence of a father is reliable an indicator of criminal behavior. The control of children is less if they are single-parent families, this especially applies to fatherless families. An argument for our claim is that the absence of father contribute to the propensity to commit juvenile delinquency can be found in research by psychiatrist Kelam Sheppard. He came to the conclusion that the boys who were older than ten years old and who grew up with only their mother are more prone to delinquency behavior than the children who have grown up in families where the father was present (Nikolić-Ristanović \& Konstantinović-Vilić, 2018).

Numerous studies have been conducted on the relationship between family relationships and manifestations of aggression. Studies have shown that only $8 \%$ of minors starts with criminal behavior, whereby their fathers are not criminals, while $37 \%$ youth who has the father who is convicted for various offenses become delinquent (Siegel \& Welsh, 2016).

In order to consider the category of young people, and to see what the criteria for sanctioning delicacy are, it is necessary to define what it represents. Youth explicates the phase of the life cycle that is set between childhood and adulthood (or between adolescence and adulthood), which is a social construct just as all other age groups are. The youth category contains a consensus on the existence of some biological facts (e.g. universal ontogenesis, biophysical maturation as a key youth marker) and awareness of their socially conditioned articulation. When it comes to young people, biological age is primarily postulated, and we talk about many varieties of constructs and lived realities within that lifetime. The age range that characterizes this age is different. Today, youth lasts longer, i.e. starts earlier, and ends later. The duration of youth is different and in fact it is socially and not biologically determined. Education is primarily the factor that shortens or extends youth.

Young people as a social group have their own peculiarities. They are halfway between a child and an adult man. This social category, in psychosocial sense, is composed of those generations that are in the period of maturing personality, searching for personal identity, and trying out roles. They are distinguished by a series of characteristics that significantly and in a specific way determine their attitudes and behaviors: increased social expansiveness, openness to the new, the rejection of 


\section{8}

traditional values and norms, risk readiness, greater criticism, etc. (Bacic, 2004:6)

For childhood, it can be stated that as a rule it is marked with a high degree of parental and social care and protection."By entering into the world of young people, primary care for these young people is reduced, and their ability to have a more independent and responsible attitude towards themselves and the environment is presupposed. Parents and society continue to have a significant impact on the development of young people, but at the same time the image of relationships is more complicated, since young people are taking over certain obligations, thus becoming partners to the closer and broader community. This path of independence is not always recognizable" (Baćević, 1979, p. 11).

So we can conclude that young people represent a group at the transition between a child and an adult. "According to the Law on Juvenile Delinquents and Criminal Protection of Juveniles, a minor is considered a person who, at the time of the commission of the criminal offense, had 14, but did not reach 18 years('Zakon o Maloletnickim Uciniocima Krivicnih Dela i Krivicnopravnoj Zastiti Maloletnih Lica', 2005, para. 3)."1

Children are persons who are aged up to 14 years of age and can not be subject to criminal sanctions or other criminal measures (Jovašević, 2011 , p. 40). We can conclude that the way of sanctioning delinquency depends on the age. It is very important for a society to determine the cause of the delinquency, among which social and paternity occurrences in the family can occur, and therefore all measures are taken to identify the problems and triggers for the delicate behavior of children and young people. If it is established that the social-pathological phenomenon in the family causes a delinquent behavior, mechanisms for deterring juveniles from further criminal behavior can be initiated, and adequate psychological assistance can be provided to improve mental health and the process of re-socialization. "Crime as a complex social phenomenon could be defined as the totality of social phenomena that undermine universal social values, for which criminal sanctions are defined in the framework of criminal law (Bošković, 2012, p. 111)." Therefore, a criminal offense is the offense that is legally envisaged as a criminal offense, which is unlawful and which is concealed ('Krivicni zakon', 2014, para. 14). ${ }^{2}$

\footnotetext{
${ }^{1}$ the Law on Juvenile Offenders and Criminal Protection of Juveniles, the Official Gazette of the RS, 85/05, Art. 3

${ }^{2}$ Criminal Law, the Official Gazette of the RS, no. 85/05, 88/05, correction 107/05 correction $72 / 09,111 / 09,121 / 12,104 / 13$, and 108/14, art. 14
} 
On the other hand, when criminality is approached from the sociological side, it is a somewhat wider definition, because in addition to the very criminal act, it includes the both causes, conditions, consequences and perpetrators of the crime. Criminality in a sociological sense can in fact be any asocial and deviant behavior that is not in line with socially accepted norms. Crime as one of the types of deviant behavior, is in direct relation with other social-pathological phenomena, that is, it can appear as their cause, but also as their direct or indirect consequence."Accordingly, when it comes to youth delinquency, risk factors and protective factors are reduced to four groups, namely family factors, school factors, community-based factors and individual factors. In the same way, preventive activities aimed at contributing to the prevention of crime through social development are also classified, and the social prevention program itself is directed towards the individual if the individual factors are expressed, that is, towards the social environment, if the risks arise from the family, school, etc..." (Vuković, 2011, pp. 95111).

The term "juvenile delinquency" or delinquency is a legal term that includes offenses that would be considered criminal in the event that they were committed by an adult (for example, theft and murder), as well as behaviors that are considered prohibited in children, but not in adults age (alcohol abuse, car driving, running away from home) (Milojević \& Dimitrijević, 2012, p. 72). Juveniles in Serbia make up about $7 \%$ of the total number of criminally sanctioned or convicted persons, most often committing criminal offenses against property and criminal offenses against life and body. $81 \%$ of juvenile perpetrators are punished for criminal offenses against property and $8 \%$ for criminal offenses against life and body, and that a steady increase in the share of crimes against life and body in the total crime of juveniles is evident (Igrački \& Ilijić, 2016).

If we take into account the various causes favouring the onset and development of crime, it may be easy and wrong to ignore the responsibility of the individual for his own actions, or for the commission of criminal acts. However, individual actions can contribute to the emergence of crime, but we should not look for causes in them, but in different factors in the society, culture, educational, economic and political system, and above all in the family milieu, that is, in family values that can directly influence the potential of criminal activities of individuals (Bjelajac, 2013, p. 81).

If minors grow up directly looking at the criminal behavior of their parents, they lose the sense of distinguishing good from bad, in 
accordance with the general social values. Regardless of which family member to work, the awareness of minors is susceptible to environmental influences, especially family's. By observing a family member in the commission of various criminal offenses, the juvenile accepts such a pattern of behavior as normal, acceptable, even binding, in order to create a greater sense of belonging and connection with the family. Most of those who deal with criminal activities are brought to justice, and then it is inevitable that a criminal sentence be pronounced against that person. If it is a prison sentence for one (or both parents), the minor automatically remains without a parent at a specific time. All of this can cause condemnation of society, and the minor becomes marked in that same society, which brings negative consequences for his/her social and emotional development. In such situations, the juvenile generally decides on delinquent behavior, on the one hand, by looking at the parents or the other family member, believing that the same is expected from him/her or that he/she can not be expected more or better of, given whose child he/she is, on the other hand, delinquent behavior can arise as a product of an act of revolt due to the behavior of one or both parents, and as a simple attraction and seeking attention, but also in response to the reaction of the society.

A more serious situation exists when the criminal acts of a parent or other family member are directed to the minor, that is, when the minor is a victim. In this case, the effects of this social-pathological phenomenon towards the minor are far more destructive. In such circumstances, the role of a relative or institution through social support is extremely important in order to guide the minor to a different behavioral pattern, and in order to replace the sense of security and certainty that was lacking up to then, otherwise, the minor generalizes such behavior models and uses them for understanding and behavior in other situations in the future, both to the environment, both to the partner, to the authorities and to their own children (Milojević \& Dimitrijević, 2012, p. 76).

It is particularly difficult to deter a juvenile from criminal and deviant behavior if parents directly direct, incite and involve minors in their own criminal activities.

All the foregoing points to the very great importance of the family in the formation of the child's personality, as well as his/her socially acceptable or unacceptable behavior. It is precisely because of the importance of maintaining adequate family values and functional family climate, that it is necessary for society to influence those segments of family life, when it starts to disturb its harmonic functioning. 
Criminal behavior, juvenile delinquency, family pathology, are pathological social phenomena that social pathology deals with. "In a certain sense, social pathology can be defined as a set of unfavorable phenomena that are contrary to generally accepted values and norms in a civilized society (Bošković, 2012, p. 18)." Deviance, in this context, is a deviation from certain established norms, the established standard of values, laws and rules, and inevitably proposes the question of which behavior is considered deviant? It could be said that deviant ones should be considered behaviors that result in destructive and delinquent phenomena that are accompanied by formal or informal negative social reactions. The perception of social deviations, or their reduction to forms of social pathology, is the most widespread aspect of theoretical approach to the typology of social deviations, and in that sense they include criminality, alcoholism, prostitution, drug addiction, gambling, and others.

There is a wide spectrum of different motives, conditions, causes, and reasons that can lead to social deviance. The form of the manifestation of deviant behavior, as well as the intensity, type, mode, and pace depend on them. One of the most important factors is certainly the family.

In addition to individual delinquency factors such as low intelligence, poor school performance, poor empathy, aggression, hyperactivity and attention deficit, an important factor of delinquency, both in adolescents and adults, is the family factor. Conflicts in the family, inconsistent discipline, affective coldness and hostility of parents, poor monitoring and non-involvement of parents in everyday life of the minor, but also his/her psychological and emotional state, as well as crime and alcoholism in the family, can be significant factors, causers, and triggers of the appearance of delinquency behaviour (Šobot et al., 2010, p. 58).

It is therefore necessary to work advisory and educate as great percentage of families as possible about the significance of each move of parents during the upbringing on the healthy development of the child. The moment an individual accepts to start a family, he/she should think about the lives he/she will raise, as well as about his/her responsibility for socialization, cultivation and individualization of the child. The parent is, from the birth of his/her child to the moment when the child is fully grown (although even then the child is not saturated with parental love and support), responsible for managing the adequate education of his/her child, by personal examples, emotional support and uncompromising love. 


\section{BIBLIOGRAPHY:}

Ariès, P. (1973). L'enfant et la vie familiale sous l'Ancient Régime. Éditions du Seuil.

Baćević, L. (1979). Mladi u sistemu masovnog komuniciranja. Istraživačko-izdavački centar SSO Srbije.

Bjelajac, Ž. (2013). Organizovani kriminalitet: Imperija zla. Pravni fakultet za privredu i pravosuđe.

Bošković, M. (2012). Kriminologija. Pravni fakultet.

Durkheim, E. (1956). Education and Sociology. Free Press.

Golubović, Z. (1997). Antropologija u personalističkom ključu. Gutenbergova galaksija.

Igrački, J., \& Ilijić, L. (2016). Kriminalitet maloletnika-Stanje u svetu i u Srbiji. Strani Pravni Život, 1, 185-200.

Jovašević, D. (2011). Maloletničko pravo. Pravni fakultet, Centar za publikacije.

Kecman, B. (2007). Psihosocijalna porodična patologija i delinkventnost. Engrami, 29(1-2), 29-38.

Kostić, M. (2011). Ličnost maloletnog delinkventa-Kriminološka obeležja. Teme, 35(2), 475-493.

Krivicni zakon. (2014). Službeni glasnik RS, 118.

Milić, A. (1981). Domaćinstvo porodica i brak u Jugoslaviji: Društveno-kulturni, ekonomski i demografski aspekti promene porodične organizacije. Institut za sociološka istraživanja Filozofskog fakulteta $\mathrm{u}$ Beogradu.

Milić, A. (2001). Sociologija porodice: Kritika i izazovi. Čigoja štampa.

Milojević, S., \& Dimitrijević, A. (2012). Socio-emocionalni model maloletničke delinkvencije i njegove praktične implikacije. Engrami, 34(4), 71-85.

Mitrović, L. R. (1997). Sociologija. Institut za političke studije : Udruženje Nauka i društvo Srbije.

Mladenović, M. (1973). Uvod u sociologiju porodice. Savremena administracija.

Murdock, G. P. (1940). The Cross-Cultural Survey. American Sociological Review, 5(3), 361-370. https://doi.org/10.2307/2084038 
Nikolić-Ristanović, V., \& Konstantinović-Vilić, S. (2018). Kriminologija. Prometej.

Parsons, T., \& Bales, R. F. (1955). Family, socialization and interaction process. Free Press.

Rot, N. (1994). Osnovi socijalne psihologije (9th ed.). Zavod za udžbenike i nastavna sredstva.

Siegel, L. J., \& Welsh, B. C. (2016). Juvenile Delinquency: The Core (6th edition). Cengage Learning.

Slavković, A. R., \& Slavković, V. R. (2019). Psihološki i porodični faktori koji utiču na pojavu maloletničke delinkvencije. Sinteze - Časopis Za Pedagoške Nauke, Književnost i Kulturu, 15, 51-66. https://doi.org/10.5937/sinteze8-21235

Šobot, V., Ivanović-Kovačević, S., Marković, J., Srdanović-Maraš, J., \& Mišić-Pavkov, G. (2010). Maloletnička delinkvencija. Engrami, 32(3), 53-61.

Vuković, S. (2011). Savremeni pristupi i problemi u socijalnoj prevenciji kriminala. Bezbednost, Beograd, 53(3), 95-111.

Zakon o maloletnickim uciniocima krivicnih dela i krivicnopravnoj zastiti maloletnih lica. (2005). Službeni Glasnik RS, 85.

\section{PORODIČNE PRILIKE I ODNOSI KAO FAKTOR KRIMINALITETA KOD DECE}

\section{Mirjana M. Markovićl Miloš Lakićević ${ }^{2}$}

Sažetak: Statistika pokazuje da globalno raste stopa kriminala. Ni jedan period razvoja ljudskog duštva nije bio pošteđen od patoloških pojava i devijantnog ponašanja, pa ni savremeno doba, gde se može, zapravo primetiti eksplozija različitih oblika devijantnog ponašanja. Koji su to uslovi i uzroci koji su uslovili ovakve globalne trendove? U ovom radu analiziraće se porodične prilike i odnosi kao faktor kriminaliteta. Sagledaće se, koje su to univerzalne i nepromenjene karakteristike porodice, kako ona utiče na socijalizaciju, kultivaciju i individualitaciju dece. Na jedan sistematski način će se pokušati dati odgovor na univerzalna pitanja uticaja porodice na njene članove. Kakvi su ti

\footnotetext{
${ }^{1}$ mirjanamar76@gmail.com, Visoka škola strukovnih studija za obrazovanje vaspitača Pirot

${ }^{2}$ milos@kib.edu.rs, Univerzitet Privredna akademija u Novom Sadu
} 
134

interaktivni odnosi između članova porodice? Kako to utiču funkcionalne, a kako disfunkcionalne porodice na svoje članove? Da li i kako porodica može stvoriti pogodnu klimu za devijantno ponašanje i kako izbeći umnožavanje patoloških pojava kod disfunkcionalnih porodica? Sve su to pitanja na koja će se pokušati dati odgovor, iako taj odgovor verovatno neće biti jednodimenzioni, jer porodica predstavlja jednu složenu društvenu grupu, sa složenim mehanizmom delovanja.

Ključne reči: porodica, socijalizacija, deca, mladi, maloletnička delinkvencija, devijantno ponašanje

Примљен: 26.11.2019.

Прихваћен: 01.06.2020.

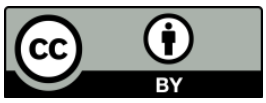

